\title{
Sexism in Elementary EFL Textbooks: Spotted in Uzbekistan
}

\author{
Nasiba Norova \\ University of Massachusetts Boston, United States \\ nasiba.norova001@umb.edu
}

\begin{abstract}
Received : 2020-07-11
Revised : 2020-08-10

Accepted : 2020-08-13
\end{abstract}

ARTICLE HISTORY

\section{KEYWORDS}

EFL textbooks

Textbook evaluation

Gender analysis

Critical discourse analysis

\begin{abstract}
The current study examines the representation of gender in four English as a Foreign Language (EFL) textbooks, namely Kids' English, for elementary students produced in Uzbekistan. The study implements Fairclough's (2013) three-dimensional discourse approach: description, interpretation, and explanation for textbook analysis. The quantitative analysis of EFL textbooks unveiled an imbalance in gender representation, in which males are depicted considerably more than females. Underrepresentation of females in the textbooks demonstrates that Kids' English EFL textbooks contain a sexist ideology and stereotypical agenda. The study suggests that the sexist ideology of the textbooks perpetuates patriarchy and unfair gender societal values, thereby hindering the development of gender equality efforts in the EFL context of Uzbekistan.
\end{abstract}

\section{Introduction}

The constructive function of textbooks in facilitating structured lesson plans, providing linguistic input in activities, tasks, texts, and visuals have been exhaustively reiterated in the literature (Hutchinson \& Torres, 1994; Shannon, 2010; Sheldon, 1987). The textbooks have been mentioned as a resource for illustrating the societal structures, values, and norms (Aljuaythin, 2018; Amerian \& Esmaili, 2013, 2015; Lee, 2018; Parham, 2013). Over the last decades, there has been a significant interest in the investigation of gender representation in English as a Foreign Language (EFL) textbooks as well (Derin et al., 2020). This interest is mostly driven by misrepresentation of genders in relation to their social and domestic roles and the social activities they are engaged in. Also, this interest has been fostered by the influential role of textbooks on young language learner's gender identity formation, future career dreams, and inspirations.

This research is a foremost critical study examining gender representation in English textbooks in Uzbekistan. Central Asian country Uzbekistan has never been an area of critical investigations either by local or international scholarship. By examining these textbooks, the study informs about the gender ideology represented in these textbooks and raises awareness of accountable bodies such as the Ministry of Education of Uzbekistan, textbook publishers, and the association of English teachers.

The post-Soviet government of Uzbekistan has made a step toward creating gender-fair society bypassing "Gender Equality Law" in 2019. The significance of the study lies in the fact that it is the first critical examination of the gender representation in EFL textbooks produced in the understudied country. By examining the EFL textbooks, the study aims to enrich the field of gender studies and material evaluation by adding a study conducted in the barely studied Central Asian context of Uzbekistan. The study also intends to inform the government of Uzbekistan of its shortcomings in textbook production.

\subsection{Context of Uzbekistan}

After gaining independence in 1991, a post-soviet Uzbekistanexperienced hardship in many domains of life, including but not limited to social, economic, political, and educational because of the slow postcommunist transition (Kangas, 2002). After the fall of the Soviet Union, the onset of the de-russification policy paved the way for the increased attention to the English language (Smagulova \& Ahn, 2016). The English instructions of 1990s were based on grammar translation and audiolingual methods and they would not start until middle school, specifically at Grade 5. The textbooks used for English classes were primarily produced in Russia and taught at Uzbek schools (Hasanova, 2007, 2016; Hasanova \& Shadieva, 2008). There was a dire shortage of teaching materials, textbooks, workbooks, teaching manuals, educational tools, and audio-visual resources in all subject classrooms including English classrooms. Due to the pressing need, the country could no longer borrow textbooks from its former oppressor. Therefore, with the help of British Council, the Ministry of Education of Uzbekistan published their first textbooks, Fly High English and English Matters, to teach English at Grades 6-9 (Hasanova, 2007). 
Considering the popularity of the English language in the globe, later, the Ministry of Education made a fundamental change in its policy, allowing the students to learn English from elementary school at Grade 1. English language as a school subject was added to the elementary school curriculum since 2013 following the president's 2012 decree (LezUZ, 2012).

In EFL contexts, language teachers are given more authority and freedom in choosing their pedagogical approaches, policies, including textbooks (Ellis 1997; Hutchinson, 1987). However, this is not the case in the post-Soviet country of Uzbekistan. The approved textbooks by the Ministry of Public Education must be produced in Uzbekistan for Uzbek English learners. Due to the 2012 decree on foreign language policy, books such as Kids' English designed for elementary school has been developed and tested in 2013. Kids' English textbooks have been in use since then and have become the sole mandatory textbook used in the entire republic.

Not only foreign language teaching system experienced improvements, but the social and political life of citizens also dramatically transformed. Even though the constitution of Uzbekistan guarantees equal rights to all citizens, males and females never had equal rights in real life due to cultural and religious traditions. In 2019, the country introduced a substantial judicial reform in history, i.e., it passed a law on gender equality with USAID's support. The law defines what gender-based discrimination is and comprises legal actions that needed to be taken to confront it. Thanks to this law, discrimination against women cannot be ignored in the Uzbek society, as well as Uzbek mentality and traditions are no longer accepted as an excuse for unfair gender treatment (USAID, 2019)

Passing the first gender equality law is the key step for founding gender-fair society in Uzbekistan. The present study aims to examine if the government's efforts to promote a "gender-equal" society by equating women's status to the men's is reflected in contemporary elementary school textbooks. This study is inspired by the key role of school textbooks in children's formation of gender-based attitudes and behavior since schools and overall education play a significant role in establishing gender-fair society (Lee, 2014, 2018).

\section{Literature Review}

\subsection{Role of Textbooks in EFL context}

Despite technological advancements occurring in the educational field, and students' sophistication in technological devices such as computers and phones, textbooks remain as the mainstay element in EFL classrooms (Hutchinson \& Torres, 1994; Junaidi et al., 2020). Undeniably, the language learning process is a dynamic and highly interactive with constant three elements: teacher, learner and textbook (Allwright, 1981). A textbook in this interaction aims to provide linguistic awareness and communicative ability to foreign language learners of English. The textbook also serves as a reference and resource for students who enjoy learning a language outside of the classroom setting (Sheldon, 1987). It is the main source of English input in the classroom in the form of texts, activities, explanations, and visual learning resources (Shannon, 2010).

Language instructors also take advantage of having textbooks in the classrooms. First of all, the teacher's syllabi are structured and backed up with the content of the textbooks. They are also, as Hutchinson $\&$ Torres argue, "[...] the most convenient means of providing the structure that the teaching-learning system requires" (p. 317). The structure backed up by textbooks further builds routinized and predictable teaching practice, which is important for language learners to avoid their linguistic anxiety (Derin \& Hamuddin, 2019; Prabhu, 1992). The facilitating role of textbooks, such as saving some time to plan the lesson, discussions, and homework assignments, has been exhaustively mentioned in the literature (Sheldon, 1987, 1988; Hutchinson \& Torres 1994). Most importantly, the textbooks have been acknowledged to give "confidence and security" (Hutchinson, 1987; Hutchinson \& Torres 1994) equally to both novice and experienced teachers. Moreover, textbooks are physical artifacts that play a central and integral part in the learning process, and they are here to stay, so they not only survive in the modern era of digitalization but also prosper within (Mohammadi \& Abdib, 2014; Sheldon, 1988).

Despite being a constructive resource by both learners and teachers in EFL classrooms, textbooks have scrutinized scrutiny and evaluation. Even though there is no "rule-of-thumb activity, and no neat formula, grid, or system [...] a definitive yardstick" (Sheldon 1988, p. 245) for textbook evaluations, some scholars use checklists or questionnaires to check the appropriateness for the use of the textbook (Ellis, 1997; Litz, 2005; Sheldon 1988). Ellis (1997) suggests predictive (pre-use) and retrospective (postuse) evaluation to determine which textbooks are best suited to teachers' purposes. Litz (2005) suggests using a questionnaire that includes categories such as practical considerations, layout, and design, skills, language type, subject, and content for the same purpose. Sheldon (1988) advocates a rating sheet that includes criteria for evaluation such as rationale, availability, layout/graphics, accessibility, authenticity, cultural bias, educational validity, overall value for money, to name but a few.

Textbooks contain many multimodal semiotics, such as texts, colorful images, signs, and symbols. Historically, images emerged before the scripts, and they were invented for communication even before 
humans developed their linguistic speech. The images embody both form and meaning and are considered as signs or semiotics (Kress, 2010). This semiotics is the basis of "visual literacy" and is described as "a matter of survival" (Kress \& van Leeuwen, 2006, p. 3). Kress \& van Leeuwen (2006) argue that visual elements interact with the reader and distribute informational value as they express meaning through color, tone, framing, and other categories and communicate meaning to viewers (Salbego et al., 2015). Kress (2010) suggests a multimodal approach to image analysis drawing from Halliday's (2014) systemic functional linguistics emphasizing representational, interactive and compositional meanings of images (Kress \& van Leeuwen, 2006). Kress's multimodal semiotic approach considers images as meaning makers describing social realities, social environment, social relations, as well as social changes (Bezemer \& Kress, 2010).

\subsection{Language, Gender and Textbooks}

It is commonly accepted that gender is a biological phenomenon. However, many would argue the cultural paradigm of the concept. Gender is culturally constructed (Butler, 1988, Sunderland 2006), so do gender roles, identities, different feminine, and masculine characteristics which are assigned to genders conventionally. Butler (1988) asserts that "gender reality is performative, which means, [...] it is performed" (p. 530). It means that masculinity and femininity do not pre-exist in society, but rather a society itself constructs gender identities, gender roles, the way these genders speak, and the way they have to behave to be a proper male or female. The assigned roles to different genders result in different gender "performances," "enactments," and "displays" of genders. This gendered performativity is enacted by social and linguistic practices (Holmes and Meyerhoff, 2003; Sunderland, 2006).

Attention to language and gender did not emerge until the feminist rise in the late 1960s. Since then, many scholars have paid attention to the linguistic performativity of gendered discourse (Sunderland, 2006). Being the key tool for the performativity of gender roles, language can adversely affect the fair representation of genders. Language can be used to stereotypical implant views and can contribute to the construction and maintenance of gender stereotyping (Sahmeni \& Afifah, 2019). So, school textbooks inevitably serve as commodities to represent and transmit political, social, economic, and cultural views (Shannon, 2010). They are also sites for social and cultural bias to be represented (Ulum \& Köksal, 2019), therefore becoming an object of criticism (Khodabakhshi, 2014). Even though designers and developers of textbooks put much effort on such a demanding work by taking a plethora of factors into account, such as age, ethnicity, class, gender, level, and purpose of the curriculum, some cultural aspects such as balanced and unbiased gender representation are frequently disregarded to date (Amerian \& Esmaili 2013, 2015; Ulum \& Köksal, 2019).

Frequent exposure to the unequal and partial depiction of males and females in the textbooks can construct gender identities in young language learners', which might conflict with the expansion of gender equality efforts in contemporary society (Aljuaythin, 2018; Mustapha, 2013). Correspondingly, stereotypical portrayals of the genders and underrepresentation of a particular gender affect children's development, put a specific constraint on their career goals, and shape their perspective on their imminent roles (Hamilton et al, 2006). Therefore, it is significantly important for textbooks, as a vital tool for learning language and social structures, to display non-sexist and gender-fair materials, so that young language learners could establish their true gender identity and believe in their abilities to reach equal opportunities as human beings despite their gender (Amerian \& Esmaili 2013, 2015; Hamilton et al, 2006; Lee 2014, 2018; Parham, 2013).

\subsection{Empirical Studies on Gender Representation in EFL Textbooks}

EFL textbook image analysis has been conducted by many scholars in the Asian context. While some Asian countries such as Iran, Saudi Arabia, and Japan are prolific in this regard (Aljuaythin, 2018; Amerian \& Esmaili, 2013, 2015; Lee, 2018; Parham, 2013), there seems to be no critical textbook research in Central Asian context particularly in EFL context of Uzbekistan to challenge the current societal situation. It is because critical thinking is absent in Uzbekistan (Khamidova, 2018) to conduct critical book evaluations. The existing studies on gender representation in the textbooks conducted in the Asian EFL other than Uzbekistan have demonstrated diverse stereotypical views and gender discriminating ideologies.

In some empirical studies on gender representation in EFL textbooks, women have disproportionately low representation in comparison to men (Amerian \& Esmaili, 2015; Aljuaythin, 2018; Ahmad \& Shah, 2019; Parham, 2013). The overrepresentation of males and underrepresentation of females was reflected on the activity the genders were engaged in, and through the social roles the genders performed (Aljuaythin, 2018); unequal representation of genders in the textbook displayed males in dominant and influential positions while females were illustrated in dependent and inferior positions (Ahmad \& Shah, 2019). Some studies revealed overt and covert sexism (Amerian \& Esmaili, 2015) and overt depiction of the secondary role of females (Lee, 2018) with clear gender bias towards females (Parham, 2013). The findings of the studies identified that EFL textbooks do not reflect the actual situation of societal structures 
causing hindrance to the course of attaining gender equality in society (Aljuaythin, 2018; Lee, 2018), as well as hindering to explore the students' full potential in their gendered identities (Amerian \& Esmaili, 2013, 2015).

As most studies conclude, education holds responsibility for the future of society (Ahmad \& Shah, 2019; Aljuaythin, 2018; Amerian \& Esmaili, 2013, 2015; Lee, 2014, 2018; Parham, 2013). Imbalanced representation of females and males, sexist and stereotypically biased representation of genders perpetuate the invisibility and inferiority of females in society. Similar to other studies, the current study aims to investigate the textbooks to see if they meet the current needs of Uzbekistan, striving to create non-sexist and gender-fair society. To do so, the study aims to investigate the ratio of the frequency of female and male images; female and male's social and domestic roles; activities females and males attend; and female and male's pictorial representations in elementary textbooks used in Uzbekistan.

\section{Method}

The study investigates EFL elementary textbooks Kids' English 1, 2, 3, and 4 produced for Uzbek English learners utilising critical discourse analysis (CDA) approach. The present study combines CDA with gender studies to identify actual gender representation in the textbook. The study implements Fairclough's (2013) three-dimensional discourse approach. The study considers that it is valid and fair to implement a European-based CDA framework for the analysis of the textbooks produced in Uzbekistan even though it is located in the Asian continent. Despite diverse mentality, societal, and cultural structures, modern Uzbekistan is striving to integrate equal gender rights law into its society and become similar to the Western countries.

\subsection{Materials}

As mentioned above, English instructions at elementary schools have been started from 2013 in Uzbekistan. Thus a need for textbooks aimed to teach English to Uzbek elementary students emerged since then. Uzbek scholars worked in collaboration with foreign institutes such as Norwich Institute for language education, IATEFL, and British Council to produce Kids' English textbooks for elementary school students. Accordingly, Uzbekistan produced Kids' English 1, 2, 3 and 4 to teach respective classes. Kids' English 1, 2, and 3 aiming to teach Grades 1, 2, and 3 respectively were reissued in 2016 and 2017 years. Kids' English 4 for Grade 4 students was published in 2016 and was not reissued. The study selected the latest issues of the textbooks Kids' English 1, 2, 3, and 4 for the analysis.
The textbooks are available online at www.hasanboy.uz website for free to download. The researcher needed to use electronic copies of the books because of the inability to obtain physical copies due to travel restrictions in and outside the United States (US). So, the electronic copies were downloaded from the above-mentioned website as it was the only website that had provided EFL books in pdf format. The reason behind selecting elementary school EFL textbooks is that they are rich in pictures and serve as an initial and primary source of the language.

\subsection{Methodological Framework}

CDA as a field can be integrated with different domains including textbooks and teaching materialevaluation. For CDA, "language is a part of society, linguistic phenomena are social phenomena of a special sort, and social phenomena are (in part) linguistic phenomena" (Fairclough, 2013 p. 19). Language is not perceived only orally or in written forms, but through visual language too, such as pictures on posters, images in books, magazines. They are ubiquitous in modern life and are of great importance to get the message, as they convey and represent particular meaning (Fairclough, 2013).

The study analyzed gendered images (images with either gender) as linguistic items from selected Kids English 1-4 textbooks using Fairclough's threedimensional CDA framework, i.e., description, interpretation, and explanation. The first stage of the framework is the description. In this stage of analysis, images are identified, labeled, and classified, since this stage is concerned with "formal properties" of the images. The second stage is concerned with the provision of interpretation of the labeled gendered pictures. The interpretation is achieved concerning the background cognitive assumptions of the person who makes the interpretation. The third stage is an explanation. As Fairclough (2013) clarifies, "explanation is concerned with the relationship between interaction and social context, the social determinations of the processes of production and interpretation, and their social effects," (p. 22). At this stage, it is possible to see visual language as a social practice depicting, sustaining and shaping social structure. Fairclough also adds, "the relationship of discourses to processes of struggle and power relations is the concern of the third stage of the procedure, explanation" (2013, p. 117).

Through the explanation stage, the analysis connects gendered images to the social context and social structures of Uzbek society and exposes if the images communicate stereotypical views about genders. To sum, through CDA's three-dimensional model, it is possible to disclose gender ideology portrayed on EFL textbooks for language learners. 


\subsection{Procedure}

For the image analysis, the study adopts Amerian $\&$ Esmaili's sex stereotype's concept $(2015$, p. 6) to identify how genders are represented in the textbooks. Amerian \& Esmaili's (2015) study contains eight factors determining gender ideology represented through pictures on the textbooks. The study adopts four of those factors because only these four out of eight quantitatively approach image analysis. The factors are as follows:

a) The ratio of the frequency of female and male images;

b) Female and male's social and domestic roles;

c) Activities females and males attend;

d) The female and male's pictorial representations.

The image analysis began by analyzing the aforementioned four aspects by counting the images manually. To verify the reliability of the collected data, the numbers and frequencies were checked and reviewed three times by the researcher. After compiling the quantitative data illustrating four investigating factors, the analysis proceeded with a qualitative interpretation of these factors in relation to the social context of Uzbekistan.

\section{Findings}

The first stage of Fairclough's CDA framework is the description. In this stage the identified, labeled and classified images are described according to four research questions mentioned earlier.

\subsection{The Ratio of Female and Male Images}

The first analyzed factor in the four elementary textbooks was the ratio of female and male images in the textbooks. As shown in Table 1, in all textbooks, female images fall behind in number in comparison to male images. While there are 502 female images in four textbooks, the male images totaled 611 occurrences. These numbers indicate that male occurrence is $0.8 \%$ more than female occurrence resulting in the disproportionate representation of genders in the textbooks.

Table 4.1 Frequency of Female and Male Occurrences

\begin{tabular}{ccc}
\hline Textbooks & Female & Male \\
\hline Kids' English 1 & 135 & 175 \\
Kids' English 2 & 151 & 184 \\
Kids' English 3 & 123 & 147 \\
Kids' English 4 & 93 & 105 \\
Total & 502 & 611 \\
\hline
\end{tabular}

\subsection{Male and Female Social and Domestic Roles}

The second examined factor was the social and domestic roles associated with each gender. As shown in Table 2, some roles were dominated by either gender or were occupied exclusively by one. For instance, females outnumbered males in occupations such as teaching (32), selling (11), and medicine (doctors/nurse 8) while men outnumbered women in jobs like sports (21) and police (10). Some occupations were demonstrated as of particular gender's occupation as well. The occupations such as a driver (7), a fireman (7), and a director (2) were exclusively men's domain, while a dancer (10) and a secretary (3) were women's exclusive area of work. Only a cook (4) as a social role and daughter/son/ sibling domestic roles were shown almost equally by both genders (20 for males and 21 for males).

Table 4.2 Social and Domestic Female and Male Roles

\begin{tabular}{lcc}
\hline \multicolumn{1}{c}{ Roles } & Female & Male \\
\hline Student & 149 & 178 \\
Teacher & 32 & 8 \\
Doctor/nurse & 8 & 1 \\
Sportsman & 12 & 21 \\
Parent & 7 & 4 \\
Sibling/son/daughter & 20 & 21 \\
Salesperson & 11 & 1 \\
Policeman & 2 & 10 \\
Secretary & 3 & 0 \\
Cook & 4 & 4 \\
Director & 0 & 2 \\
Dancer & 10 & 0 \\
Fireman & 0 & 7 \\
Driver & 0 & 7 \\
\hline
\end{tabular}

\subsection{Activity Frequency of Females and Males}

The third examined factor was the activity types males and females engaged in the images. Similar to domestic and social roles occurrences, the quantitative analysis of activities undertaken by both genders was either dominated by one gender or done by one gender more than the opposite. To be specific, as it is shown in Table 4.2, the images illustrated males doing sports and working on the computer more than females ( $16 \& 8$ vs $7 \& 2$ accordingly), while pictures illustrating females playing games and talking on the phone (30 \&8 vs $23 \& 2$ ) are more in number. While morning exercises are exclusively performed by male characters (4), household chores are carried out only by female characters (7). The table also shows that the only shared activity both genders participated was singing (3). 
Table 4.3 Female and Male Activities

\begin{tabular}{lcc}
\hline \multicolumn{1}{c}{ Activities } & Female & Male \\
\hline Engaging in sports & 7 & 16 \\
Exercising & 0 & 4 \\
Talking on the phone & 8 & 2 \\
Shopping & 2 & 1 \\
Watching TV & 3 & 2 \\
Horse riding & 4 & 0 \\
Computer work & 2 & 8 \\
Playing games & 30 & 23 \\
Household chores & 7 & 0 \\
Traveling & 0 & 1 \\
Fishing & 0 & 2 \\
Singing & 3 & 3 \\
Taking pictures & 1 & 0 \\
& & \\
\hline
\end{tabular}

\subsection{Pictorial Representation of Males and Females}

The fourth investigated factor is related to female and male pictorial representation.

Table 4.4 Pictorial Representation of Females and Males

\begin{tabular}{lc}
\hline Pictorial Representation & Kids' English 1-4 \\
\hline Females only & $46(15 \%)$ \\
Males only & $74(24 \%)$ \\
More males & $63(20 \%)$ \\
More females & $33(11 \%)$ \\
Equal share & $92(30 \%)$ \\
\hline Total & $\mathbf{3 0 8}$ \\
\hline
\end{tabular}

As shown in Table 4.4, out of 308 pictures, 92 of them portray equal categories depicting an equal number of males and females. Female only images consist of $15 \%$ of all images, while male-only images outnumber the former to $9 \%$. Mixed-gender pictures depicting males more consist of a fifth of all images in EFL textbooks, and group images depicting more females comprise merely $11 \%$ of all images.

\section{Discussion}

The second and third stages of Fairclough's model deal with interpretation and explanation of the data in relationship with the social context and social processes of Uzbek society since the textbooks are produced by and for the Uzbek learning population. Correspondingly, the findings unveiled three themes: "sexism and stereotyping in the textbooks," "perpetuation of patriarchal values", and "lack of women empowerment". Thus, the current study contributes to the pool of scholarly work on textbook evaluation by exposing the gender ideology of the Uzbekistan context represented in its English textbooks.

\subsection{Sexism and Stereotyping in the Textbooks}

The underrepresentation of females in the textbooks indicates that the Kids' English 1-4 have sexist ideology as there is an imbalanced representation of males. With the representation of females being outnumbered, the textbooks can also be interpreted as promoting the superiority of males over females.

The sexist view is seen not only in the image occurrences but also in the domestic and social roles they perform. The real-life females working as firefighters, drivers, office workers or the females working on the computer, engaged in other activities other than teaching and doing household chores, are not exemplified. These sexist views on women stereotype them and impose on generalizable assumptions to the young learners. For instance, seeing women talking on the phone more than men engender the stereotypical idea of "chatty idler woman" or women working as sales personnel demonstrates that they cannot pursue careers requiring mental and physical strength. These depictions are unrealistic and do not depict the actual social structure of Uzbek society. Even though the number of women performing male's roles and activities is fewer, they are neither invisible nor nonexistent. Dismally, the findings of this study are consistent with other studies conducted in the Asian context (Aljuaythin, 2018; Ahmad \& Shah, 2019; Amerian \& Esmaili, 2013, 2015; Lee, 2014; Parham, 2013), suggesting that EFL textbooks promote a certain degree of sexism against women due to the overrepresentation of males and stereotyping of women.

\subsection{The Perpetuation of Patriarchal Values}

The dissymmetry in the representation of males and females also reflects patriarchal values set on the male gender in Uzbek society. The reports on "gender assessment in Uzbekistan" produced by Asian Development Bank $(2014,2018)$ demonstrate that patriarchal norms and gender stereotypes are persistent in existence in Uzbek society. The reports also suggest that these norms are the main obstacle for societal development in creating a gender-fair society. According to the report, the Uzbek model of patriarchy is mostly seen in the labor division. In which males are responsible for the material and financial burden of the household and taking care of the family budget. At the same time, females are responsible for managing household chores, taking care of their family members and the offspring's upbringing, and education.

The illustrative representation of women doing nurse/doctor jobs or being engaged in cooking in the kitchen or doing household chores at home are examples of labor division set by the patriarchal family. Males doing computer work, engaged in driving, or well-paid occupations such as firefighter, director or police also indicate male's concern for sustaining the family at home as if they are "the only breadwinners" of the family. 
Clearly, the textbooks are picturing the unreal social structure of Uzbek families and promoting patriarchy. The promotion of patriarchy and patriarchal values were also found in other studies (Aljuaythin, 2018; Sulaimani, 2017). Apparently, the EFL textbooks are involved in the perpetuation of patriarchal society and patriarchal ideology. As Sunderland (2006) argues, "patriarchy is women's struggle" (p. 21), which is contrary to the fairness and equality efforts the government of Uzbekistan is attempting to establish since 2019. The patriarchal values portrayed in EFL textbooks empower only males and sustains gender inequality in Uzbek society.

\subsection{Deficiency of Women Empowerment}

Last but not least, the underrepresentation of females, the attached stereotypical views to them, and the perpetuation of patriarchal values through EFL textbooks establish a solid foundation for the disempowerment of women within Uzbek society. Such textbooks do not empower women to share tasks equally; they do not inspire to have a variety of career choices or to perform diverse activities merely due to their gender.

The lack of such encouragement in the elementary EFL textbook creates an obstacle for women empowerment. Language education, through EFL textbooks, should facilitate "emancipatory discourse" (Fairclough, 2013) in order "to ultimately transform the dominant orders of discourse, as a part of the struggle of oppressed social groupings," (p. 198). The struggle women are facing in Uzbek society is partially portrayed realistically through domestic roles, social roles and activities both genders are engaged in. Sadly enough, the textbooks neither teach to break nor to challenge societal structure, but add to the growth of gender bias, inequality, and disparity.

\section{Conclusion}

The current study investigated the representation of gender in four Uzbek EFL textbooks for elementary school students. It aimed to analyze gender representation in these textbooks to see if EFL textbooks assist in the government's aim to create a "gender-equal" society and to add to the field of material evaluation and gender representation, for only a few studies have focused on this issue. The goal of the paper is to debunk gender dissymmetry in textbooks to inform educational officials to call for improvement. The significance of the study is that there is no other study aimed to evaluate elementary English textbooks used in the context of Uzbekistan. The paper is also a primary work critically approaching EFL textbook analysis used in Uzbekistan using Fairclough's (2015) threedimensional framework to critical discourse analysis. The quantitative analysis unveiled an imbalance in Uzbekistan's gender representation as males are depicted more than females. Underrepresentation of females in the textbooks proves that the EFL textbook Kids' English has a sexist ideology and sets stereotypical agenda on them. The study suggests that this, consequently, perpetuates patriarchy and unfair gender societal values hindering the development of gender equality efforts in Uzbekistan.

Nonetheless, some limitations need to be mentioned. Also scrutinising middle and high school EFL textbooks could contribute to fully comprehend the gender ideology predominant in EFL textbooks used in Uzbekistan. Additionally, incorporating a multimodal semiotic approach to textbook evaluations could yield different results. Including texts as a new semiotic dimension, in addition to the visuals, would reveal new facets of gendered societal reality presented in the textbooks (Bezemer \& Kress, 2010; Kress, 2010; Kress \& van Leeuwen, 2006). Analyzing language use in relation to genders could be another dimension for a semiotic approach to textbook evaluations.

This study has some pedagogical implications for language classrooms. It is highly recommended for the Uzbek EFL teachers to adopt a critical perspective on societal issues, such as gender fairness, and bring it to the classroom table when they notice stereotypical propaganda or sexism in textbooks. Also, it is worth bringing other materials to the language classrooms which do not reflect gender bias towards either of the genders. Undoubtedly, the Ministry of Education of Uzbekistan should revise the content of the published books and pay close attention to the balanced, unbiased, unsexist representation of both females and males in the textbooks aimed at educating young Uzbek language learners. Following a long-term goal of the Uzbek government to create a gender-fair society, there should be teacher training, and support programs to equip teachers with a critical perspective toward gender ideologies to further challenge, break, and transform them in their classrooms and in the society in the long run.

It is worth restating that the textbooks in most EFL contexts, including Uzbekistan are the primary source of not only language learning (Hasanova, 2007), but also of education in general, socialization with the outer world, and increasing cultural awareness. Education influences students' identity formation, including national and gender identities (Ahmad \& Shah, 2019). Correspondingly, school education has a transformative power, and it is responsible to a great extent for the unfair gender differences which might occur in society in the future (Parham, 2013).

Therefore, all school subjects, not just English as a Foreign Language, should also hold responsibility for the future of the students who are growing up as members of Uzbek society. Raising awareness and consciousness to the societal practices through 
language education is necessary for breaking, challenging, and transforming societal orders (Fairclough, 2013). Because the long-term goal of education is establishing gender-fair society which will provide equal opportunities and rights for both genders, the effort should start from the beginning, from the initial classes of compulsory education, from elementary school.

\section{References}

Ahmad, M., \& Shah, S.K. (2019). A Critical Discourse Analysis of Gender Representations in the Content of 5th Grade English Language Textbook. International and Multidisciplinary journal of social Sciences, 8(1), 1-24. http:// dx.doi.org/10.17583/rimcis.2019.3989

Ahn, E., \& Smagulova, J. (2016). Language Change in Central Asia. De Gruyter.

Al Jumiah, A. K. (2016). Language, Power, and Ideology in High School EFL Textbooks in Saudi Arabia. (Doctoral of Philosophy), the University of New Mexico, Albuquerque, New Mexico.

Aljuaythin, W. (2018). Gender Representation in EFL Textbooks in Saudi Arabia: A Critical Discourse Analysis Approach. International Journal of Applied Linguistics \& English Literature, $\quad 7(5), \quad 151-157$. http://dx.doi.org/10.7575/aiac.ijalel.v.7n.5p.15 1

Allwright, R. L. (1981). What Do We Want Teaching Materials for? ELT Journal 36(1), 5-18.

Amerian, M., \& Esmaili, F. (2013). Gender Representation in Iranian High School English Textbooks with a Critical Discourse Analysis Perspective. International Journal of Language Learning and Applied Linguistics World, 5(4), 277-289.

Amerian, M., \& Esmaili, F. (2015). Language and Gender: A Critical Discourse Analysis on Gender Representation in a Series of International ELT textbooks. International Journal of Research Studies in Education, 4(2), 3-12.

Asian Development Bank. (2014). Uzbekistan Country Gender Assessment. https://www.adb.org/sites/default/files/instituti onal-document/42767/files/uzbekistan-countrygender-assessment.pdf.

Asian Development Bank. (2018). Uzbekistan Country Gender Assessment. Creative Commons Attribution.

Bezemer, J., \& Kress, G. (2010). Changing Text: A Social Semiotic Analysis of Textbooks. Design for learning, 3(1-2), 10-29.
Butler, J. (1988). Performative Acts and Gender Constitution: an Essay in Phenomenology and Feminist Theory. Theatre Journal, 40(4), 519531.

Derin, T., \& Hamuddin, B. (2019). Foreign Language Classroom Anxiety, and Enjoyment During Study Abroad: A Review of Selected Paper. Lisan: Jurnal Bahasa dan Linguistik, 8(2), 7682. https://doi.org/10.33506/li.v8i2.367

Derin, T., Susilo Putri, N., Nursafira, M. S., \& Hamuddin, B. (2020). Discourse Analysis (DA) in the Context of English as a Foreign Language (EFL): A Chronological Review . ELSYA : Journal of English Language Studies, 2(1), 1-8. https://doi.org/10.31849/elsya.v2i1.3611

Ellis, R. (1997). The Empirical Evaluation of English Teaching Materials. ELT Journal Volume 51(1), 36-42.

Fairclough, N. (2013). Language and Power ( $2^{\text {nd }}$ ed). Routledge.

Halliday, M.A.K. (2014). Halliday's Introduction to Functional Grammar (4th ed.). Routledge.

Hamilton, M.C., Anderson, D., Broaddus, M. \& Young, K. (2006). Gender Stereotyping and Under-representation of Female Characters in 200 Popular Children's Picture Books: A Twenty-first Century Update. Sex Roles, 55, 757-765. https://doi.org/10.1007/s11199-006-9128-6

Hasanova, D. (2007). Teaching and Learning English in Post-Soviet Uzbekistan. English Today, 89(23), 3-9.

Hasanova, D. (2016). English Education in Uzbekistan. In A. Ahn \& J. Smagulova (Eds.), Language Change in Central Asia (pp. 245267). De Gruyter.

Hasanova, D., \& Shadieva, T. (2008). Implementing Communicative Language Teaching in Uzbekistan. TESOL Quarterly, 42(1), 138-143.

Holmes, J., \& Meyerhoff, M. (2003). Handbook of Language and Gender. Blackwell Publishing.

Hutchinson, T. (1987). What's Underneath? An Interactive View of Materials Evaluation. In L. Sheldon (Ed.), ELT Textbooks and Materials: Problems in Evaluation and Development (pp. 37-45). Modern English Publications.

Hutchinson, T., \& Torres, E. (1994). The Textbook as Agent of Change. ELT Journal, 48(4), 315328.

Junaidi, J., Hamuddin, B., Simangunsong, W., Rahman, F., \& Derin, T. (2020). ICT Usage in Teaching English in Pekanbaru: Exploring 
Junior High School Teachers' Problems. International Journal of Advanced Science and Technology, 29(3), 5052-5063. http://sersc.org/journals/index.php/IJAST/articl e/view/5725

Kangas, R. (2002). Uzbekistan: the Karimov presidency-Amir Temur Revisited. In S.N. Cummings (Ed.), Power and Change in Central Asia (pp. 130-150). Routledge.

Khamidova, S. (2018). Civil Society in Uzbekistan: Building from the Ground Up. EUCAM Commentary, 31, 1-4. https://eucentralasia.eu/2018/07/civil-societyin-uzbekistan-building-from-the-ground-up/

Khodabakhshi, M. (2014). Choose a Proper EFL Textbook: Evaluation of "Skyline" Series. Social and Behavioral Sciences, 98, 959-967.

Kress, G. R. (2010). Multimodality: A Social Semiotic Approach to Contemporary Communication. Routledge.

Kress, G. R., \& Van Leeuwen, T. (2006). Reading Images: The Grammar of Visual Design. London, England: Routledge.

Lee, J. F. (2014). Gender Representation in Hong Kong Primary School ELT Textbooks - A Comparative Study. Gender and Education, 26 (4), 356-376.

Lee, J. F. (2018). Gender Representation in Japanese EFL Textbooks - A Corpus Study. Gender and Education, 30(3), 379-395. https://doi.org/10.1080/09540253.2016.121469 0 .

LexUZ. (2012). On Measures to Further Improve the System of Learning Foreign Languages, https://www.lex.uz/docs/-2126032

Litz, D. (2005). Textbook Evaluation and ELT Management: A South Korean Case Study. Asian EFL journal, 48(1), 1-53.

Mohammadi, M., \& Abdib, H. (2014). Textbook Evaluation: A Case Study. Social and Behavioral Sciences, 98, 1148 - 1155.

Mustapha, A. S. (2013). Gender and Language Education Research: A Review. Journal of Language Teaching and Research, 4(3), 454463. doi:10.4304/jltr.4.3.

Parham, F. (2013). Gender Representation in Children's EFL Textbook. Theory and Practice in Language Studies, 3(9), 1674-1679, https://doi.org/10.4304/tpls.3.9.1674-1679.

Prabhu, N. S. (1992). The Dynamics of the Language Lesson. TESOL Quarterly, 26(2), 161-76.
Sahmeni, E., \& Afifah, N. (2019). Using Critical Discourse Analysis (CDA) in Media Discourse Studies: Unmask the Mass Media. REiLA: Journal of Research and Innovation in Language, 1(2), 39-45. https://doi.org/10.31849/reila.v1i2.2764

Salbego, N., Heberle, V., \& da Silva Balen, M. (2015). A Visual Analysis of English Textbooks: A Multimodal Scaffolded Learning. Calidoscópio, 13(1), 5-11.

Shannon, P. W. (2010). Textbook development and selection. In International Encyclopedia of Education (pp. 397-402). Elsevier Ltd. https://doi.org/10.1016/B978-0-08$\underline{\text { 044894-7.00065-8 }}$

Sheldon, L. (1987). ELT textbooks and materials: Problems in Evaluation and development. Modern English Publications.

Sheldon, L. E. (1988). Evaluating ELT textbooks and materials. ELT journal, 42(4), 237-246.

Sulaimani, A. (2017). Gender Representation in EFL Textbooks in Saudi Arabia: A Fair Deal? English Language Teaching, 10(6), 44-52. doi:10.5539/elt.v10n6p44.

Sunderland, J. (2006). Language and Gender. An advanced resource book. Routledge.

Ulum, G., \& Köksal, D. (2019). Ideology and Hegemony of English Foreign Language Textbooks. Globally and Locally Written Practices. Springer.

USAID. (2019, December 19). Uzbekistan passes law on gender equality. USAID. https://www.usaid.gov/uzbekistan/programupdates/dec-2019-uzbekistan-passes-lawgender-equality 